\title{
ANALYSIS OF SERIOUS AND FATAL OCCUPATIONAL ACCIDENTS ASSOCIATED WITH TRACTORS IN AGRICULTURE AND FORESTRY IN THE CZECH REPUBLIC
}

\author{
Zuzana Valeriánová1 ${ }^{\text {Zdeněk Patočka² }}$ \\ ${ }^{1}$ Department of Engineering, Faculty of Forestry and Wood Technology, Mendel University in Brno, Zemědělská 1, \\ 61300 Brno, Czech Republic \\ ${ }^{2}$ Department of Forest Management and Applied Geoinformatics, Faculty of Forestry and Wood Technology, \\ Mendel University in Brno, Zemědělská 1, 61300 Brno, Czech Republic
}

Link to this article: https://doi.org/10.11118/actaun202068040719

Received: 19. 11. 2019, Accepted: 19. 6. 2020

To cite this article: VALERIÁNOVÁ ZUZANA, PATOČKA ZDENĚK. 2020. Analysis of Serious and Fatal Occupational Accidents Associated with Tractors in Agriculture and Forestry in the Czech Republic. Acta Universitatis Agriculturae et Silviculturae Mendelianae Brunensis, 68(4): 719-727.

\begin{abstract}
Agriculture and forestry have traditionally been one of the most hazardous occupations for workers. In both these sectors the tractor is one of the most used machinery. From a total of 89 detected serious and fatal accidents with tractors in the Czech Republic between the years 2009 and 2018 were 72 serious and 17 fatal. All the accidents affected men (no woman was affected). Men around 56 with low practice length were most at risk of injury. Categories created by the State Labour Inspection Office of the Czech Republic assign exactly one category to each injury. The most common cause of the accident was poor or insufficiently estimated risk (in 62 of 89 cases). Own accident categories were created, and more than one category of cause was assigned to one injury if found. The most common cause of the accident was an incorrect procedure and breach of rules. The analysis of accidents and related information revealed that out of 89 cases the injury became most often to a tractor operator (in 47 cases) and outside the cab (in 50 cases). Within the labour relations, $14 \%$ of the injuries were fatal and $86 \%$ were serious; outside of labour relations, $67 \%$ of the injuries were fatal and $13 \%$ were serious.
\end{abstract}

Keywords: accident, agriculture, forestry, injury, labour relations, risk, tractor

\section{INTRODUCTION}

More than 2.78 million people die every year as a result of occupational accidents or workrelated diseases and an additional 374 million workers suffer from non-fatal occupational accidents (Wadsworth and Walters, 2019). Agriculture and forestry have traditionally been very hazardous sectors for workers (International Labour Organisation, 2015; International Labour Organisation, 2005). In 2017, there were 2.4 cases of incapacity for work per 100 insured persons due to an accident at work in the CZ-NACE group "Agriculture, Forestry and Fisheries", which was the highest of all 20 monitored groups (Czech Statistical Office, 2018). The most used machine in agriculture is traditionally a tractor (Cavallo et al., 2014; Ayers and Khorsandi, 2017). It is also often used in forestry (Akay, 2005; Spinelli et al., 2015; Magagnotti and Spinelli, 2011). To reduce the incidence of accidents with tractors and propose corrective action for a particular situation, it is necessary to know many facts to understand why the accident happened. Therefore, this article deals with the analysis of 
serious and fatal accidents with a tractor (what caused the accident, who was affected by it, where it happened, etc.) in the Czech Republic for ten years.

\section{MATERIALS AND METHODS}

From the information system of the State Labour Inspection Office of the Czech Republic, serious and fatal injuries whose accident report involved a tractor in the Agriculture, Forestry and Logging category between the years 2009 and 2018 in the Czech Republic were selected. Accident reports and related information were studied, and the cases in which tractors were involved in the accident were included in further research. A total of 89 accident reports and related data (activity during the accident, source of injury, place of injury, cause of injury, age, sex and years of practice, employment relationship, etc.) were examined and statistically evaluated in TIBCO Statistica software. First relations were determined by dividing data into groups using k-means cluster analysis based on age and practice length. The Kolmogorov-Smirnov test for the distribution analysis of practice length and age between serious and fatal injuries was performed. Correlation between age, practice length and factors of injuries were determined using Kendall's tau correlations. A contingency table was created and dependencies between the case and factors of injuries and severity of work were analyzed using the chi-square test of independence.

\section{RESULTS}

From a total of 89 detected serious and fatal accidents with tractors in the Czech Republic between the years 2009 and 2018 were 72 serious (injured person was treated in the hospital for more than 5 days after the accident) and 17 fatal (injured person died within one year after the accident). All the accidents affected men (no woman was affected). Further details are provided in the following analyses.

\section{Cluster Analysis by Age and Practice Length}

The average age of a man who suffers a serious or fatal occupational injury with a tractor was 45.0 years. In the case of 86 persons for whom the figure was known, the average number of practice lengths at the accident date was 11.0 years. Cluster analysis was performed, in which workers were divided into three groups according to their age and years of practice, where:

- in Group 1, the average age of persons involved was 55.0 years and they worked on average 37.0 years,

- in Group 2 the average age of persons involved was 56.6 years and they worked on average 8.8 years,

- in Group 3, the average age of persons involved was 27.5 years and they worked on average 3.5 years (Fig. 1 ).

\section{Relation Between Work Injury Severity and Age}

Frequency histograms of practice length for serious and fatal injuries are displayed in Fig. 2. and Fig. 3.

The Kolmogorov-Smirnov test was performed for the analysis, whether a group of serious injuries and a group of fatal injuries have the same probability distribution of worker's age. P-value was higher than the significance level alpha $=0.05$, the null hypothesis was accepted. There are no differences in worker's age distribution between serious and fatal injuries.

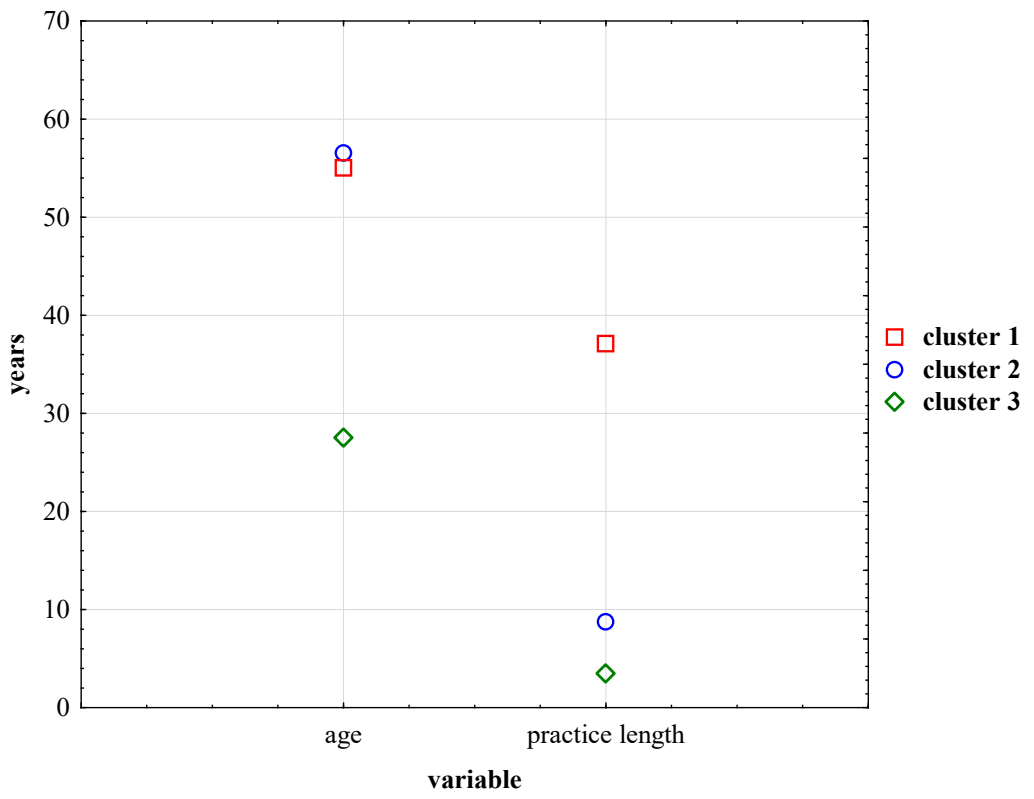

1: Cluster analysis by age and practice length 


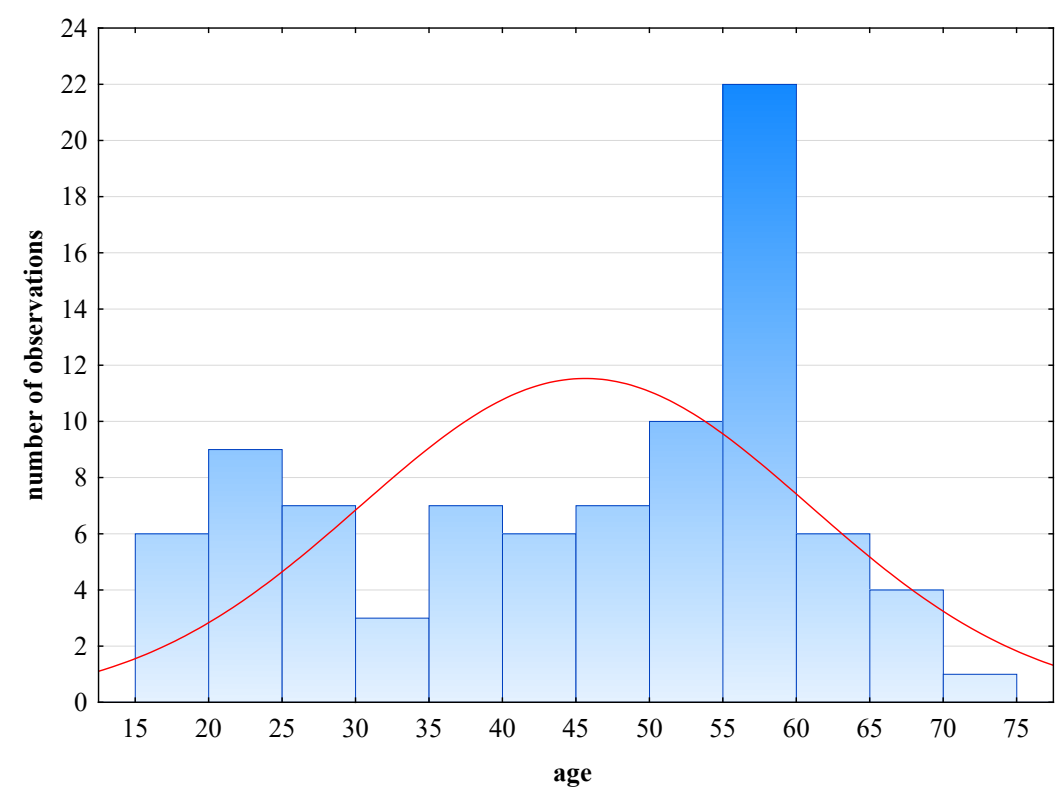

2: Frequency histogram of age for serious injuries (red line is theoretical normal distribution)

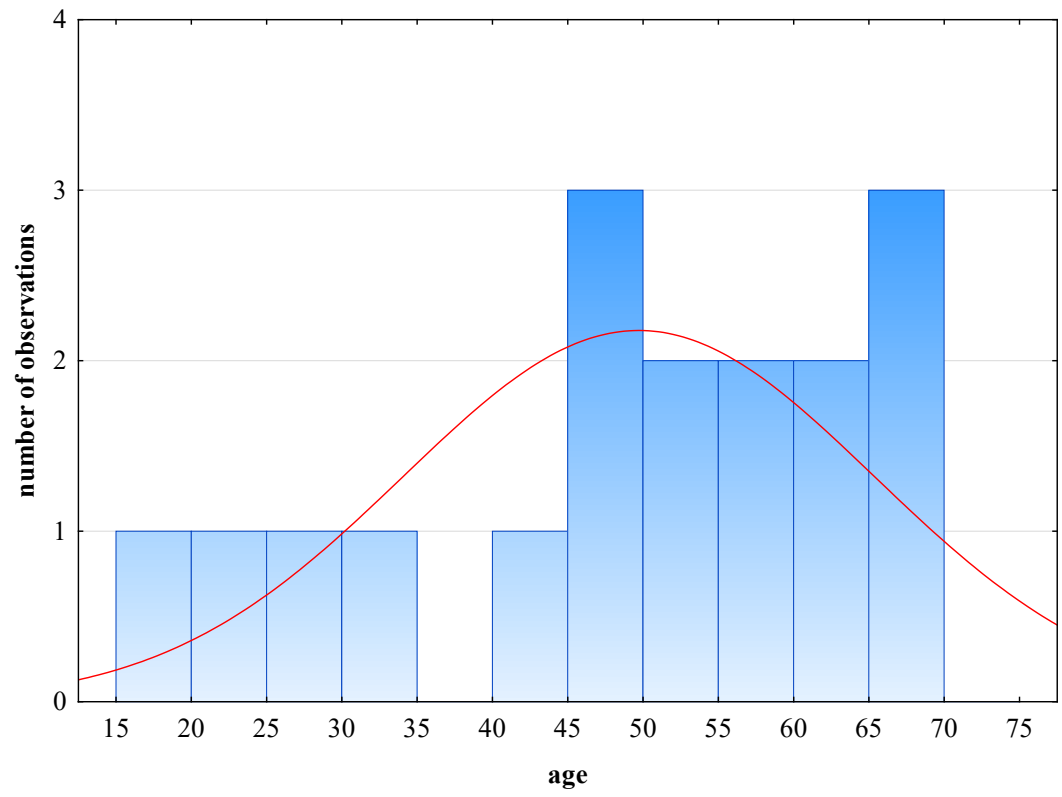

3: Frequency histogram of age for fatal injuries (red line is theoretical normal distribution)

\section{Relation Between Work Injury Severity and Practice Length}

Frequency histograms of practice length for serious and fatal injuries are displayed in Fig. 4. and Fig. 5.

Kolmogorov-Smirnov test was performed for the analysis, whether a group of serious injuries and a group of fatal injuries have the same probability distribution of practice length. P-value was lower than the significance level alpha $=0.05$, the null hypothesis was rejected. There are differences in practice length distribution between serious and fatal injuries.

\section{Analysis of the Causes of Injuries}

The frequency of the causes of injury was evaluated within the categories defined by the State Labour Inspection Office of the Czech Republic, which assigns exactly one category to each injury. It was found that 62 of the injuries were caused by poorly or insufficiently estimated risk, 7 by using unsafe practices or working methods (including work without authorization, against prohibition, stay in danger area) and only 14 injuries resulted from other causes, which are more detailed in Tab. I. 


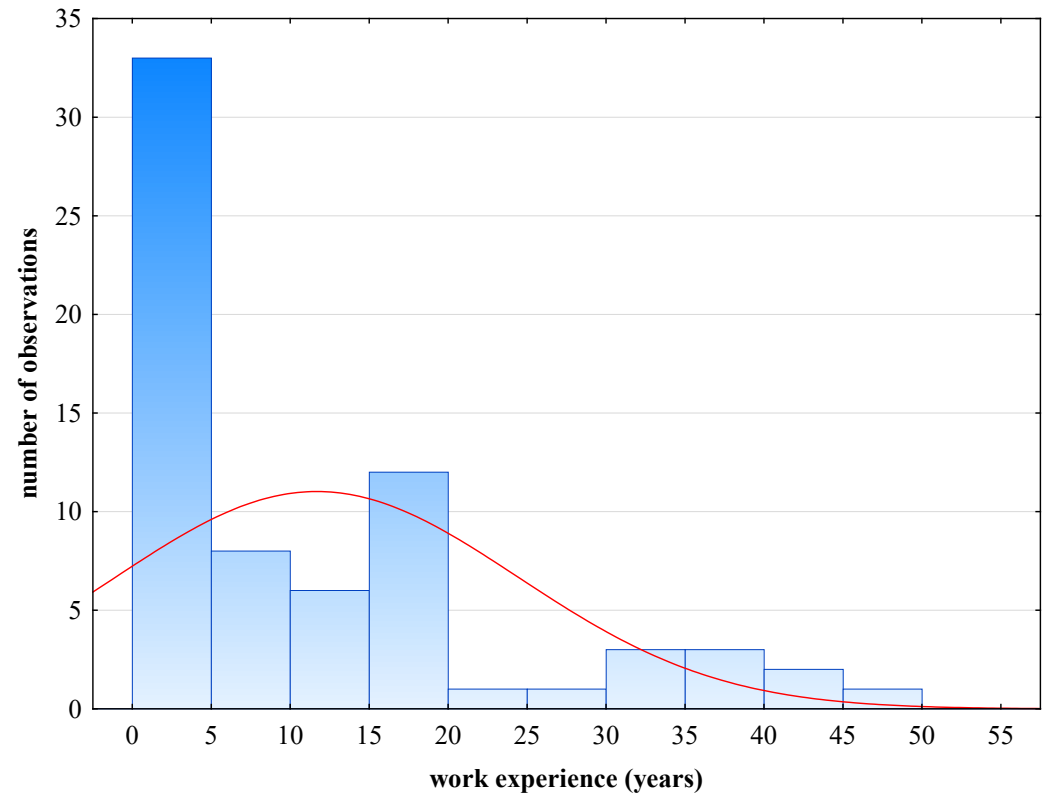

4: Frequency histogram of work experience for serious injuries (red line is theoretical normal distribution)

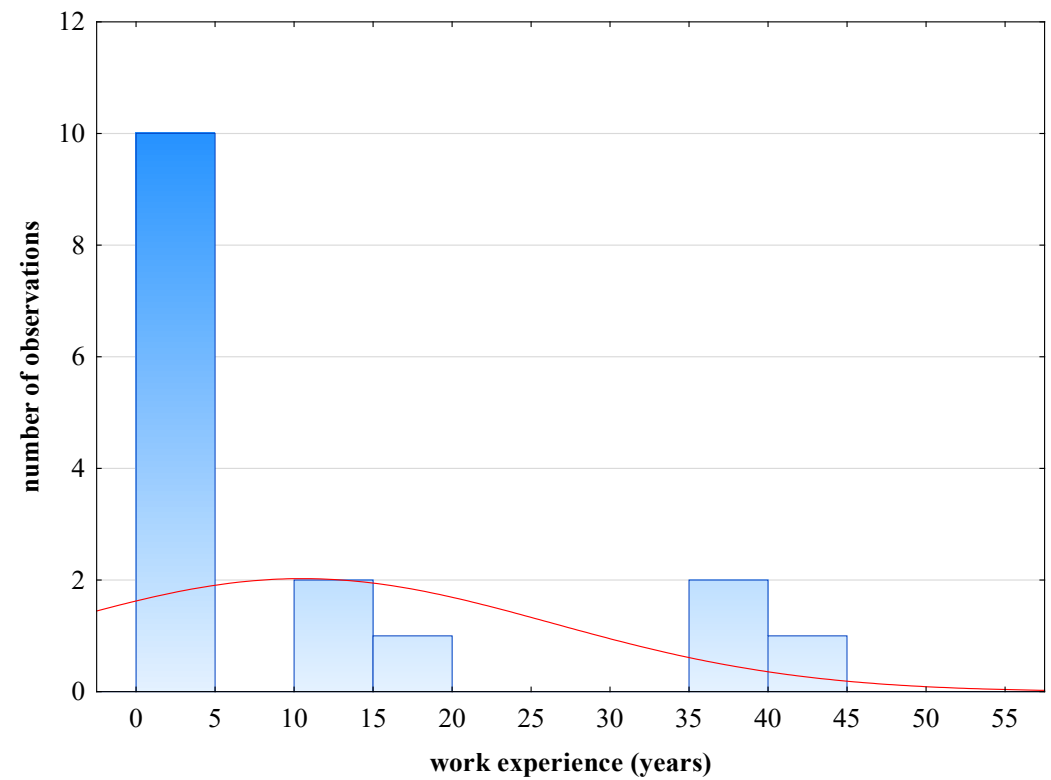

5: Frequency histogram of work experience fatal injuries (red line is theoretical normal distribution)

Using the chi-squared test of independence, the null hypothesis of variables independence (categories of accident causes and severity of the work injury) was tested and the p-value was found to be smaller than 0.05. Therefore the null hypothesis was rejected and it was stated that is a difference in injury cases between fatal and serious injuries.

In particular, the Tab. I shows a higher incidence of unsafe practices or working methods in cases of fatal accidents.

According to the most frequent causes of injury in the accident reports and related information own categories of causes of accidents (except categories registered by the State Labor Inspection Office) were created:

- failure - caused - the cause or one of the causes of the injury was a machine or tool failure that was caused directly by the injured or other workers;

- failure - not caused - the cause or one of the causes of the injury was a machine or tool failure that was not immediately caused by the injured or other workers;

- failure - not detected - the cause or one of the causes of the injury was a machine or tool failure, 


\begin{tabular}{|c|c|c|c|c|c|c|}
\hline \multirow{3}{*}{ Categories of accidents causes } & \multicolumn{6}{|c|}{ Number of accidents } \\
\hline & \multicolumn{2}{|c|}{ Serious } & \multicolumn{2}{|c|}{ Fatal } & \multicolumn{2}{|c|}{ Total } \\
\hline & $\mathrm{n}$ & $\%$ & $\mathrm{n}$ & $\%$ & $\mathrm{n}$ & $\%$ \\
\hline The poor or insufficiently estimated risk & 53 & 72.6 & 9 & 56.3 & 62 & 69.7 \\
\hline $\begin{array}{l}\text { Unsafe practices or working methods (including work without } \\
\text { authorization, against prohibition, stay in danger area) }\end{array}$ & 2 & 2.7 & 5 & 31.3 & 7 & 7.9 \\
\hline Not identified & 5 & 6.8 & 1 & 6.3 & 6 & 6.7 \\
\hline $\begin{array}{l}\text { Deficiencies of personal prerequisites for proper work performance (lack } \\
\text { of physical prerequisites, sensory deficiencies, unfavorable personal } \\
\text { characteristics, and immediate psychophysiological states) }\end{array}$ & 5 & 6.8 & 0 & 0.0 & 5 & 5.6 \\
\hline $\begin{array}{l}\text { Threatened by other persons (distraction at work, pranks, quarrels, and } \\
\text { other wrong or dangerous actions of others) }\end{array}$ & 3 & 4.1 & 0 & 0.0 & 3 & 3.4 \\
\hline Wrong organization of work & 1 & 1.4 & 1 & 6.3 & 2 & 2.2 \\
\hline Defective or unfavorable condition of the source of injury (not workplace) & 2 & 2.7 & 0 & 0.0 & 2 & 2.2 \\
\hline Missing or insufficient protective devices and safeguards & 1 & 1.4 & 0 & 0.0 & 1 & 1.1 \\
\hline $\begin{array}{l}\text { Unfamiliarity with safe working conditions and lack of necessary } \\
\text { qualifications (theoretical knowledge, skills, training, adaptation, etc.) }\end{array}$ & 1 & 1.4 & 0 & 0.0 & 1 & 1.1 \\
\hline Total & 73 & 100 & 16 & 100 & 89 & 100 \\
\hline
\end{tabular}

II: The frequencies of the individual categories of accidents causes

\begin{tabular}{|c|c|c|c|c|c|c|}
\hline \multirow{3}{*}{ Categories of accidents causes } & \multicolumn{6}{|c|}{ Number of accidents } \\
\hline & \multicolumn{2}{|c|}{ Serious } & \multicolumn{2}{|c|}{ Fatal } & \multicolumn{2}{|c|}{ Total } \\
\hline & $\mathrm{n}$ & $\%$ & $\mathrm{n}$ & $\%$ & $\mathrm{n}$ & $\%$ \\
\hline An incorrect procedure, breach of rules & 28 & 35 & 9 & 50 & 37 & 37.8 \\
\hline Loss of balance & 22 & 27.5 & 0 & 0 & 22 & 22.4 \\
\hline Tractor overturning & 7 & 8.8 & 6 & 33.3 & 13 & 13.3 \\
\hline Slipping, skidding & 9 & 11.3 & 1 & 5.6 & 10 & 10.2 \\
\hline Failure - not caused & 7 & 8.8 & 0 & 0 & 7 & 7.1 \\
\hline Failure - not detected & 5 & 6.3 & 1 & 5.6 & 6 & 6.1 \\
\hline Failure - caused & 2 & 2.5 & 1 & 5.6 & 3 & 3.1 \\
\hline Total & 80 & 100 & 18 & 100 & 98 & 100 \\
\hline
\end{tabular}

but it was not possible to determine whether it was caused directly by the injured or other workers;

- slipping, skidding - the cause or one of the causes of injury was a spontaneous movement or skid off the machine (and tools);

- tractor overturning - the cause or one of the causes of the accident was the tractor overturning;

- loss of balance - the cause or one of the causes of injury was a loss of balance or a slip of the injured or other workers;

- an incorrect procedure, breach of rules - the cause or one of the causes of the accident was non-compliance with the prescribed work procedure or safety rules by the injured or other workers.
It was taken into consideration that one accident could have more than one cause and therefore more than one cause category was assigned to one injury if found. However, none of the defined categories could be assigned to the 12 injuries, because there was a road accident between the tractor and another vehicle caused by the other driver (in two cases), the injured person had a heart attack (in two cases, both resulting in death), etc. The frequencies of the individual categories of accident causes are shown in Tab. II.

The differences of cause frequencies between fatal and serious accidents were tested using chisquared test of independence. Only significant differences of cause frequencies (p-value $<0.05$ ) are shown in Tab. III. and Tab. IV. 
III: Cause - loss of balance $(p$-value $=0.00862)$

\begin{tabular}{lcccc}
\hline \multirow{2}{*}{ Type of injury } & \multicolumn{2}{c}{ Loss of balance } & \multirow{2}{*}{ Total } \\
\cline { 2 - 4 } & & Present & Absent & \\
\hline \multirow{2}{*}{ Serious } & $\mathrm{n}$ & 22 & 50 & 72 \\
& $\%$ & 30.6 & 69.4 & \\
\hline \multirow{2}{*}{ Fatal } & $\mathrm{n}$ & 0 & 17 & 17 \\
\hline Total & $\%$ & 0.0 & 100.0 & \\
\hline
\end{tabular}

IV: Cause - tractor overturning ( $p$-value $=0.00725)$

\begin{tabular}{lcccc}
\multirow{2}{*}{ Type of injury } & \multicolumn{2}{c}{ Tractor overturning } & \multirow{2}{*}{ Total } \\
\cline { 2 - 4 } & & Present & Absent & \\
\hline \multirow{2}{*}{ Serious } & $\mathrm{n}$ & 7 & 65 & 72 \\
\cline { 3 - 5 } & $\%$ & 9.7 & 90.3 & \\
Fatal & $\mathrm{n}$ & 6 & 11 & 17 \\
\hline Total & $\%$ & 35.3 & 64.7 & \\
\hline
\end{tabular}

All accidents with an identified cause - loss of balance were classified as serious.

A tractor overturning often results in a fatal injury.

Using Kendall's tau correlation, the statistical dependence between selected categories of causes of injury and the age of the operator and between these categories and the operator's practice length were determined.
The statistical correlation was found between the operator's age and the loss of balance. The other causes of the injury did not prove statistical dependence between them and the operator's age, as shown in Tab. V. The analysis has shown that older operators tend to lose of balance more often than the younger ones.

The statistical correlation was proved between the operator's practice length and the tractor overturning. The analysis has shown that operators with less experience tend to overturn the tractor more. The other causes of the injury did not prove statistical dependence between them and the operator's practice length, as shown in Tab. VI.

\section{Analysis of the Job Function of the Injured Person}

For further analysis categories of person who was affected by the injury were created:

- operator - the tractor operator has been injured;

- others - people other than the tractor operator were affected by the accident (e.g. his co-workers or people in the workplace);

- cannot be determined - it cannot be ascertained whether the tractor operator or other people have been injured.

The analysis of accidents and related information revealed that out of 89 cases the injury became a tractor operator in 47 cases, another person in 9 cases, in one case the accident occurred simultaneously to the operator and another person and in 32 cases it was not possible to determine with certainty whether the injury occurred to the tractor operator or another person. Information about the severity of injury can be found in Tab. VII.

$\mathrm{V}$ : Kendall's tau correlation between the operator's age and the cause of the injury

\begin{tabular}{lcccc}
\hline & Failure - caused & Slipping, skidding & Loss of balance & $\begin{array}{c}\text { Incorrect procedure, } \\
\text { breach of rules }\end{array}$ \\
\hline Age & 0.015062 & -0.007460 & 0.151659 & -0.024637 \\
\hline
\end{tabular}

VI: Kendall's tau correlation between the operator's practice length and the cause of the injury

\begin{tabular}{|c|c|c|c|c|c|}
\hline & Failure - caused & Slipping, skidding & Loss of balance & $\begin{array}{c}\text { Incorrect procedure, } \\
\text { breach of rules }\end{array}$ & $\begin{array}{c}\text { Tractor } \\
\text { overturning }\end{array}$ \\
\hline Practice length & -0.003282 & -0.072008 & 0.117273 & 0.054340 & -0.161940 \\
\hline
\end{tabular}

VII: Number of injuries by severity and the job function of the injured person

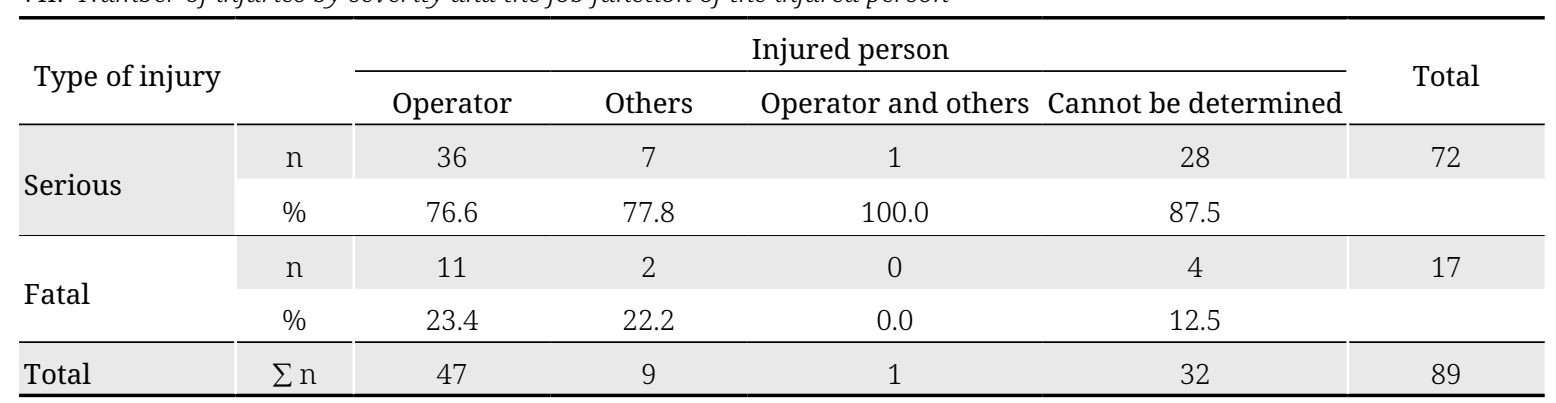


VIII: Number of injuries by severity and the location of the accident ( $p$-value $=0.0242$ )

\begin{tabular}{|c|c|c|c|c|c|}
\hline \multirow{2}{*}{\multicolumn{2}{|c|}{ Type of injury }} & \multicolumn{3}{|c|}{ Location of the accident } & \multirow{2}{*}{ Total } \\
\hline & & In the tractor & Outside the tractor & Ascent/entry & \\
\hline \multirow{2}{*}{ Serious } & $n$ & 18 & 42 & 12 & 72 \\
\hline & $\%$ & 66.7 & 84.0 & 100.0 & \\
\hline \multirow{2}{*}{ Fatal } & $\mathrm{n}$ & 9 & 8 & 0 & 17 \\
\hline & $\%$ & 33.3 & 16.0 & 0.0 & \\
\hline Total & $\sum \mathrm{n}$ & 27 & 50 & 12 & 89 \\
\hline
\end{tabular}

IX: Number of injuries by severity and the type of labor-law relationship ( $p$-value $=0.00013$ )

\begin{tabular}{|c|c|c|c|c|}
\hline \multirow{2}{*}{\multicolumn{2}{|c|}{ Type of injury }} & \multicolumn{2}{|c|}{ Type of labor-law relationship } & \multirow{2}{*}{ Tota } \\
\hline & & In labour relations & Outside labour relations & \\
\hline \multirow{2}{*}{ Serious } & $\mathrm{n}$ & 69 & 3 & 72 \\
\hline & $\%$ & 95.8 & 4.2 & \\
\hline \multirow{2}{*}{ Fatal } & $\mathrm{n}$ & 11 & 6 & 17 \\
\hline & $\%$ & 64.7 & 35.3 & \\
\hline Total & $\sum \mathrm{n}$ & 80 & 9 & 89 \\
\hline
\end{tabular}

If the injury happened to the operator, the most common cause (or one of the cause) for the injury was an incorrect procedure, breach of rules (16 cases), loss of balance (14 cases) and tractor overturning of the tractor (13 cases).

When other people were affected by the accident, the most common cause (or one of the causes) was an incorrect procedure, breach of rules (7 cases), slipping, skidding (3 cases) and tractor overturning (1 case).

\section{Analysis of the Place where the Injury Occurred}

Categories have been created to assess the location of the accident:

- in the tractor - the accident occurred in the tractor cab;

- outside the tractor - the accident occurred outside the tractor cab;

- ascent/entry - the injury occurred when getting out of or entering the tractor cab.

From the 89 considered cases, 27 of them happened in the tractor, 50 outside the tractor cab and 12 during ascent or entry. The location differences between serious and fatal injuries were tested using chi-squared test of independence. Further details are given in Tab. VIII.

In the case of accidents occurring in the tractor, the most common cause (or one of the causes) was tractor overturning (13 cases), incorrect procedure, breach of rules (9 cases) and slipping, skidding (6 cases).

If the accident occurred outside the tractor cab, the most common cause (or one of the causes) was an incorrect procedure, breach of rules (28 cases), loss of balance ( 9 cases) and failure - not caused (5 cases).
Cases that occurred when getting in or out of the tractor cab were caused in all cases by loss of balance.

\section{Analysis of the Relationship Between the Type of Labor-law Relationship and the Severity of the Work Injury}

Of the 89 serious and fatal injuries, 80 were in labor relations, 9 of them outside labor relations based on work performance agreement, agreement on work activity or as a person performing activities or providing services outside the laborlaw relationship. In the case of labor relations, 14\% of the injuries were fatal and 86\% were serious, outside of labor relations, $67 \%$ of the injuries were fatal and 13\% were serious. The Contingence table is shown in Tab. IX. Using the chi-squared test of independence, the null hypothesis of variables independence (labor relations and severity of the work injury) was tested and the p-value was found to be smaller than 0.05 . Therefore the null hypothesis was rejected and it was stated there are differences in the frequency of workers in labor and frequency of workers outside labor relation between the causes of fatal and serious relations.

\section{DISCUSSION}

The article examined serious and fatal accidents. Reporting these injuries to the State Labour Inspection Office of the Czech Republic is mandatory under the legislation, therefore, these accidents are well described. However, minor accidents and risks must also be taken into consideration. Heinrich introduced the statistical relationship between frequent minor accidents, rare serious accidents and very rare fatal accidents (Heinrich, 1941), 
which is known as Heinrich pyramid or Heinrich's Law. Although some authors question the accuracy and validity of this concept (Marshall, Hirmas and Singer, 2018), it can generally be assumed that one serious or fatal accident indicates much more minor accidents or risks.

When analyzing the causes of serious or fatal work-related accidents that occurred in connection with the tractor, according to the categorization of the State Labor Inspection Office of the Czech Republic, $69.7 \%$ of them were caused by poorly or insufficiently estimated risk. This categorization assigns exactly one cause to each accident, and it is not possible to determine why the risk was misjudged. Therefore, the own categories of causes of accidents (except categories registered by the State Labor Inspection Office) were created according to the most frequent causes of injury in the accident reports and related information. It was taken into consideration that one accident could have more than one cause and therefore more than one cause category was assigned to one injury if found. In this way, it was found that $41.6 \%$ of the injuries were caused by (or one of the causes was) an incorrect procedure or breach of rules. This situation may be due to a lack of knowledge of these rules, an inability to apply the information obtained in practice or their intentional ignorance.

The incorrect procedure or breach of rules, as well as a poorly or insufficiently estimated risk, which is closely related to the former and may be understood as its more general expression, could be solved by occupational safety training (Caffaro et al., 2018). This statement is supported by the fact that fatal occupational accidents have occurred more frequent outside the labor relations, in which workers are usually not as well trained (these relationships tend to be shorter and the level of occupational safety is not controlled at the same level as in the labor relations).

These occupational safety training should be focused especially on the people who are perceived to be the most vulnerable group - around 56 years old and with low experience, and it should be taken into consideration that $56 \%$ of accidents have occurred outside the tractor, therefore it is necessary to focus on all aspects and means of working with the tractor (e.g. also on attached tools).

Within the own categories, the second most common cause of fatal injury was a tractor overturning. The fact that tractor rollover is the leading cause of fatalities also shows the results of other authors (Rondelli, Casazza and Martelli, 2018). This situation indicates the necessity of protective elements in the design of the tractor as roll-over protective structures (ROPS) because they help protects the driver when the tractor is overturned (Ayers et al., 2018; Troyanovskaya et al., 2018) and reduce the severity of injuries.

\section{CONCLUSION}

From a total of 89 detected serious and fatal accidents with tractors in the Czech Republic between the years 2009 and 2018 were 72 serious and 17 fatal. All the accidents affected men (no woman was affected). Men around 56 with low practice length were most at risk of injury. While according to the categories created by the State Labour Inspection Office of the Czech Republic, which assigns exactly one category to each injury, the most common cause of the accident was poor or insufficiently estimated risk (in 62 of 89 cases). After the own accident categories were created and more than one cause category was assigned to one injury if found, the most common cause of the accident was an incorrect procedure and breach of rules.

The analysis of accidents and related information revealed that out of 89 cases the injury became most often to a tractor operator (in 47 cases) and outside the cab (in 50 cases). In the case of labor relations, $14 \%$ of the injuries were fatal and $86 \%$ were serious, outside of labor relations, $67 \%$ of the injuries were fatal and 13\% were serious.

Acknowledgements

We thank the employees of the State Labour Inspection Office of the Czech Republic for the provision of the input data into the analyses.

\section{REFERENCES}

AKAY, A. E. 2005. Using farm tractors in small-scale forest harvesting operations. Journal of Applied Sciences Research, 1(2): 196-199.

AYERS, P. and KHORSANDI, F. 2017. Reducing tractor rollover fatalities: Progress in ROPS technology. Resource Magazine, 24(6): 6-7.

AYERS, P. et al. 2018. ROPS designs to protect operators during agricultural tractor rollovers. Journal of Terramechanics, 75: 49-55. 
CAFFARO, F. et al. 2018. Effectiveness of occupational safety and health training for migrant farmworkers: a scoping review. Public health, 160: 10-17.

CAVALLO, E. et al. 2014. Attitudes and behavior of adopters of technological innovations in agricultural tractors: A case study in Italian agricultural system. Agricultural Systems, 130(C): 44-54.

CZECH STATISTICAL OFFICE. 2018. Incapacity for work due to disease or injury in the Czech Republic - 2017 [in Czech: Pracovní neschopnost pro nemoc a úraz v České republice - za rok 2017]. CZECH STATISTICAL OFFICE. [Online]. Available at: https://www.czso.cz/csu/czso/pracovni-neschopnostpro-nemoc-a-uraz-v-ceske-republice-za-rok-2017 [Accessed: 2019, January 20].

HEINRICH, H. W. 1941. Industrial Accident Prevention: a Scientific Approach. $2^{\text {nd }}$ Edition. New York \& London: McGraw-Hill Book Company.

INTERNATIONAL LABOUR ORGANISATION. 2015. Agriculture: A hazardous work. International Labour Organisation. [Online]. Available at: https://www.ilo.org/global/topics/safety-and-health-atwork/areasofwork/hazardous-work/WCMS_356550/lang--en/index.htm [Accessed: 2019, January 20].

INTERNATIONAL LABOUR ORGANISATION. 2005. Guidelines for labour inspection in forestry: Meeting of Experts to Develop Guidelines for Labour Inspection in Forestry. Sectoral Activites Programme. Geneva: International Labour Office.

MAGAGNOTTI, R. V. and SPINELLI, R. N. 2011. Financial and energy cost of low-impact wood extraction in environmentally sensitive areas. Ecological engineering, 37: 601-606.

MARSHALL, P., HIRMAS, A. and SINGER, M. 2018. Heinrich's pyramid and occupational safety: a statistical validation methodology. Safety science, 101: 180-189.

RONDELLI, V., CASAZZA, C. and MARTELLI, R. 2018. Tractor rollover fatalities, analyzing accident scenario. Journal of safety research, 67: 99-106.

SPINELLI, R. N. and MAGAGNOTTI, R. V. 2015: Productivity models for cable yarding in Alpine forests. European Journal of Forest Engineering, 1(1): 9-14.

TROYANOVSKAYA, I. P. et al. 2018. Estimating safety of a tractor cab with the protective system ROPS. IOP Conference Series: Materials Science and Engineering, 450(3): 032021.

WADSWORTH, E. and WALTERS, D. 2019. Safety and health at the heart of the future of work: Building on 100 years of experience. Geneva: International Labour Organization.

Contact information

Zuzana Valeriánová: xvaleria@node.mendelu.cz

Zdeněk Patočka: zdenek.patocka@mendelu.cz 